Asian J Agric \& Biol. 2021(4). $\mathrm{AJAB}$ DOI: $10.35495 / a j a b .2021 .01 .045$

Original Article

\title{
Optimization for in vitro regeneration in four local cultivars of indica rice
}

\author{
Md Taufiqur Rahman', Md. Hasanuzzaman'1, Md. Monirul Islam² ${ }^{2}$, M.T.R Mondal ${ }^{3}$, Md. Shahidul Islam¹, Nihar \\ Ranjan Saha ${ }^{1}$ \\ ${ }^{1}$ Department of Biotechnology, Bangladesh Agricultural University, Mymensingh, Bangladesh \\ ${ }^{2}$ Biotechnology Division, Bangladesh Institute of Nuclear Agriculture, Mymensingh, Bangladesh \\ ${ }^{3}$ Horticulture Division, Bangladesh Institute of Nuclear Agriculture, Mymensingh, Bangladesh
}

Received:

March 12, 2021

Accepted:

May 25, 2021

Online First:

September 21, 2021

Published:

September 21, 2021

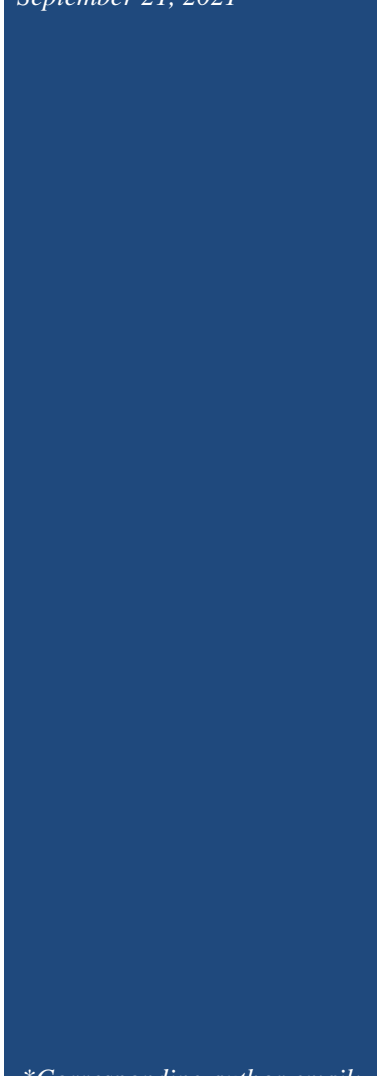

*Corresponding author email: mislambina73@gmail.com

\begin{abstract}
The current investigation was planned and designed for optimizing the concentration of plant growth regulators to generate an efficient in vitro callogenesis and plantlet regeneration in four local cultivars of Indica rice. Effects of six different concentrations of 2,4-D (2,4-dichlorophenoxyacetic acid), kinetin and carbon source, amino acids, and solidifying agents on callus induction were observed using mature seeds as starting material. Two different concentrations of NAA (1-naphthaleneacetic acid) + kinetin and IBA (Indole-3-butyric acid) were used for shoot regeneration and root induction, respectively. The highest frequency $(100 \%)$ of callus was recorded on the medium containing 2mg/l 2,4-D which was followed by $3 \mathrm{mg} / \mathrm{l} 2,4-\mathrm{D}+10 \mathrm{mg} / \mathrm{l}$ kinetin $(95.51 \%)$ at the dark condition in cultivar Sadamota. Moreover, MS (Murashige and Skoog) medium supplemented with $2 \mathrm{mg} / \mathrm{l}$ 2,4-D, L-proline and sucrose (as carbon source) increased the callus induction frequency. The highest percentages of callus induction were found when both the gelrite and agar were used as solidifying agents. The maximum shoot regeneration $(66.44 \%)$ and shoot number (4.49) were obtained at $0.50 \mathrm{mg} / \mathrm{l} \mathrm{NAA}+10 \mathrm{mg} / \mathrm{l}$ kinetin in the cultivar, Sadamota. Moreover, the highest root induction and root number were recorded at $0.50 \mathrm{mg} / \mathrm{l}$ IBA in Sadamota. Overall, the highest optimum callus induction, shoot regeneration and root formation were obtained at $2 \mathrm{mg} / \mathrm{l} 2,4-\mathrm{D}, 0.50 \mathrm{NAA}+10 \mathrm{mg} / \mathrm{l} \mathrm{kinetin}$ and $0.50 \mathrm{mg} / \mathrm{l} \mathrm{IBA}$, respectively. Sadamota exhibited the best plantlet regeneration followed by Kachamota whereas the lowest was displayed by Dudkalam. This regenerated protocol could be utilized for gene transfer in rice for the development of stress-tolerant and high yielding lines in future.
\end{abstract}

Keywords: Callogenesis, Indica rice, Mature seeds, Plant growth regulators, Plantlet regeneration

\section{How to cite this:}

Rahman MT, Hasanuzzaman M, Islam MM, Mondal MTR, Islam MS and Saha NR, 2021. Optimization for in vitro regeneration in four local cultivars of indica rice. Asian J. Agric. Biol. 2021(4): 202101045. DOI: https://doi.org/10.35495/ajab.2021.01.045

This is an Open Access article distributed under the terms of the Creative Commons Attribution 3.0 License. (https://creativecommons.org/licenses/by/3.0), which permits unrestricted use, distribution, and reproduction in any medium, provided the original work is properly cited. 


\section{Introduction}

Rice (Oryza sativa L.), an essential food crop belongs to the Gramineae family. It is usually grown and cultivated in the region of south and south-east Asia. It's providing foods for about half of the global population (Sandhu and Kumar, 2017). It contains two major subspecies, Japonica and Indica (Vaughan et al., 2003). As rice is cultivated in nearly $75 \%$ of agricultural fields, it is the most dominant food grain in Bangladesh. Our agriculture sector contributed to about $17 \%$ of the total country's Gross Domestic Product (GDP) (BBS, 2016). Farmers cultivate rice in mainly three seasons (Aman Aus and Boro) in our country around the year. Now, it's a great demand to increase rice production immediately to ensure the food demands of a continuously growing population. Moreover, the production of rice is severely affected because of various abiotic stresses including submergence. In the Southern Delta region of Bangladesh, the inundation of agricultural lands due to tidal flooding is a major threat to crop productivity (Ullah et al., 2016). In Barisal and Patuakhali districts, nearly $80 \%$ of the arable land is flooded (up to a range of 6-90 cm) during monsoonal flooding. It creates an obstacle in cultivating the modern varieties of aman rice which were developed by genetic transformation. During the rainy season, the dwarf and high yielding rice cultivars are not suitable for cultivation in the tidal floodplain region. Therefore, the farmers of this region prefer to cultivate indigenous varieties which are mostly low yielding, long-duration, photo-sensitive, and tall instead of high yielding varieties (HYVs). Some indigenous cultivars namely Moulata, Sadamota, Kachamota and Dudhkalam are usually grown and cultivated in the region of tidal floodplain in the districts of Jhalakati and Pirojpur (Shamsuzzaman and Haque, 2010). The yield of the local cultivars is extremely low and research intervention seeking yield improvement has not been substantial. Therefore, it is an urgent need to develop potential stress-tolerant and high-yielding varieties utilizing the local resource that will minimize the reduction of grain yield and overcome cultivable field limitation.

Plant tissue culture, a biotechnological technique, is successfully used worldwide for developing and maintaining genetic variability by developing a stresstolerant variety of crop plants. For developing transgenic rice, scientists rely on tissue culture-based gene transfer technology (Gosal and Kang, 2012). Moreover, establishing an efficient protocol of in vitro regeneration is a compulsory steps for the successful transformation of the desired gene. In indica rice, a few successful regeneration protocols were found (Sahoo et al., 2011). Different plant organs were used as explants especially immature embryos and mature seeds (Cai et al., 2013; Azizi et al., 2015; Kumar et al., 2017; Binte Mostafiz and Wagiran, 2018), leaf base segments (Ramesh et al., 2009), anthers (Maharani et al., 2020), microspores (Shariatpanahi et al., 2006), and immature inflorescences (Kavas et al., 2008) for callus formation and plant regeneration. Immature embryo explants have been recorded as the most competent explants for higher callus proliferation and regeneration (Yu et al., 2008; Kumar et al., 2017). The maintenance of growth conditions for immature embryos is very difficult, and this procedure is costly and very time-consuming whereas mature embryos are more compatible as they are available throughout the year. Research works on successful rice regeneration from the mature embryo have been described by many scientists (Ahmad et al., 2016; Artadana et al., 2017; Binte Mostafiz and Wagiran, 2018; Ho et al., 2018; Ming et al., 2019). Some major factors such as culture medium components, explants type, Plant Growth Regulator (PGRs) treatments, solidifying agents, and culture condition etc significantly affected the callus growth, proliferation and essential steps of regeneration. (Ge et al., 2006; Feng et al., 2011; Parmar et al., 2012; Ahmad et al., 2016; Kumar et al., 2017; Binte Mostafiz and Wagiran, 2018; Repalli et al., 2019).Therefore, our experiment was undertaken to establish a mature embryo based complete regeneration protocol in local indica rice.

\section{Material and Methods}

\section{Plant materials}

Our total experiments on assessing the callogenesis and regeneration potentials of selected rice cultivars were undertaken in the laboratory of Plant Tissue Culture of, Biotechnology Division at Bangladesh Institute of Nuclear Agriculture (BINA), Mymensingh. In our study, a total of four local cultivars of rice namely Kachamota, Sadamota, Dudhkalam and Moulota were used. The mature seeds were used as explant sources which were collected from the Barisal division of Bangladesh.

\section{Explants sterilization}

Mature de-husked seeds from each rice cultivar were 


\section{Md Taufiqur Rahman et al}

sterilized aseptically by treating with $70 \%$ ethanol (1 min) which was followed by $3.5 \% \mathrm{NaOCl}+1-2$ drops Tween-20 for 15 min. After that the sterilized mature seeds were carefully washed thrice with sterile distilled water followed by drying on autoclaved filter paper. Then the completely sterilized rice seeds were transferred to callus culture medium $(25 \mathrm{ml}$ in $90 \mathrm{~mm}$ petridish) where the seeds scutellum side was up position and plumule slightly embedded into medium under aseptic condition.

\section{Callus induction and subculture}

To prepare the callus induction medium, we have used MS culture medium which was supplemented with different carbon sources, solidifying agents and different concentrations of PGRs. The culture medium was autoclaved $\left(121^{\circ} \mathrm{C}, 20 \mathrm{~min}\right)$, after adjusting the $\mathrm{pH}$ between 5.6-5.8. Six different combination of nutrient composition and concentrations of phytohormones supplemented in culture medium for callus induction (Table 1).

Table-1. Different media composition of callus induction medium

\begin{tabular}{cl}
\hline Treatments & \multicolumn{1}{c}{ Media Composition } \\
\hline $\mathrm{T}_{1}$ & $\mathrm{MS}+2,4-\mathrm{D}(2 \mathrm{mg} / \mathrm{l})+$ sucrose $(30$ \\
& $\mathrm{g} / \mathrm{l})+$ gelrite $(6.4 \mathrm{~g} / \mathrm{l})$ \\
$\mathrm{T}_{2}$ & $\mathrm{MS}+2,4-\mathrm{D}(2 \mathrm{mg} / \mathrm{l})+$ maltose $(30$ \\
& $\mathrm{g} / \mathrm{l})+$ gelrite $(6.4 \mathrm{~g} / \mathrm{l})$ \\
$\mathrm{T}_{3}$ & $\mathrm{MS}+2,4-\mathrm{D}(2 \mathrm{mg} / \mathrm{l})+\mathrm{L}-$ proline \\
& $(0.5 \mathrm{~g} / \mathrm{l})+\mathrm{L}-\mathrm{glutamine}(0.5 \mathrm{~g} / \mathrm{l})+$ \\
& sucrose $(30 \mathrm{~g} / \mathrm{l})$ gelrite $(6.4 \mathrm{~g} / \mathrm{l})$ \\
& $\mathrm{MS}+2,4-\mathrm{D}(2 \mathrm{mg} / \mathrm{l})+\mathrm{L}-$ proline \\
$\mathrm{T}_{4}$ & $(0.5 \mathrm{~g} / \mathrm{l})+\mathrm{L}-\mathrm{glutamine}(0.5 \mathrm{~g} / \mathrm{l})+$ \\
& $\mathrm{maltose}(30 \mathrm{~g} / \mathrm{l})+\mathrm{gelrite}(6.4 \mathrm{~g} / \mathrm{l})$ \\
& $\mathrm{MS}+2,4-\mathrm{D}(3 \mathrm{mg} / \mathrm{l})+$ kinetin $(10$ \\
$\mathrm{T}_{5}$ & $\mathrm{mg} / \mathrm{l})+\mathrm{maltose}(30 \mathrm{~g} / \mathrm{l})+\mathrm{gelrite}(4$ \\
& $\mathrm{g} / \mathrm{l})+$ agar $(2 \mathrm{~g} / \mathrm{l})$ \\
& $\mathrm{MS}+2,4-\mathrm{D}(3 \mathrm{mg} / \mathrm{l})+$ kinetin $(10$ \\
$\mathrm{T}_{6}$ & $\mathrm{mg} / \mathrm{l})+$ sucrose $(30 \mathrm{~g} / \mathrm{l})$ gelrite $(4 \mathrm{~g} / \mathrm{l}$ \\
& )+ agar $(2 \mathrm{~g} / \mathrm{l})$ \\
\hline
\end{tabular}

Afterward ten finely sterilized seeds were placed in one petridish on culture medium. Parafilm was used for proper sealing and then the pertidishes were incubated in both dark and light conditions at $25 \pm$ $1^{\circ} \mathrm{C}$. After 3 or 4 days, the inoculated seeds swelled at mesocotyl and radicle regions of seeds. For achieving better callus, subcultures were carried out in 2 weeks where the primary calli were incubated on the same medium and condition for another 3 weeks.

\section{Plant regeneration}

Five weeks aged calli were transferred to the regeneration medium having different combinations of phytohormones. The hormonal combination was used for shoot regeneration were as follows: (a) MS + NAA $(0.25 \mathrm{mg} / \mathrm{l})+$ Kinetin $(10 \mathrm{mg} / \mathrm{l})$; (b) $\mathrm{MS}+\mathrm{NAA}(0.5$ $\mathrm{mg} / \mathrm{l})+$ Kinetin $(10 \mathrm{mg} / \mathrm{l})$. For regeneration, the culture conditions were maintained by adjusting the relative humidity $(45-60 \%)$, temperature $\left(25 \pm 1^{\circ} \mathrm{C}\right)$ and cool-fluorescent light $(110 \mathrm{mmol} / \mathrm{m} 2 / \mathrm{s}, 16 \mathrm{~h})$ for 4 weeks. Then, the subculture was performed one time after 2 weeks.

\section{Root induction and acclimatization}

Regenerated shoots were carefully transferred into basal MS medium (half strength) supplemented with 0.25 and $0.5 \mathrm{mg} / \mathrm{l} \mathrm{IBA}$ for facilitating root induction. The cultures were incubated at $25 \pm 1{ }^{\circ} \mathrm{C}$ and photoperiod (110 $\mathrm{mmol} / \mathrm{m} 2 / \mathrm{s}, 16 \mathrm{~h}$ ) for 2 weeks. After that, the finely rooted rice plantlets were carefully transferred into plastic pots (peat (1): vermiculite (1), keeping similar incubation conditions. When the rice plants grew 10-15 leaves, they were transferred to the greenhouse.

\section{Data collection and statistical analysis}

After 4 weeks, the callus induction percentages were determined. After 4 weeks in the regeneration medium, the percentages of shoot regeneration and shoots number per callus were determined. Furthermore, incubating for 4 weeks, the root induction percentages and the root number per plantlet were determined.

Frequencies of callus formation $(\%)=($ Number of explants producing calli/ Number of explants plated) $\times 100$

Frequencies of shoot regeneration $(\%)=($ Number of calli regenerated plantlets/ Number of calli plated for regeneration) $\times$ 100

Frequencies of root induction $(\%)=$ (Number of root generating plantlets/ Number of plantlets for root formation) $\times 100$

The Recorded data were analyzed statistically by following a Completely Randomized Design (CRD). The analysis of variance (ANOVA) was estimated according to Duncan's Multiple Range Test (DMRT). 


\section{Results}

Our current study exhibited calluses initiated from the scutellum region and it was clearly shown after a week of incubation. It was observed that callus appeared to be compact, light yellowish in color and globular in shape after 3 weeks incubation (Fig. 1c; 2b).

\section{Effects of 2,4-D on callus Induction}

Callus percentage in various cultivars ranged from $70.55 \%$ to $87.89 \%$. Among all the treatments, 2,4-D at $2 \mathrm{mg} / \mathrm{l}$ exhibited the highest $(100 \%)$ callus frequency followed by 2,4-D (3 mg/l) + kinetin (10 $\mathrm{mg} / \mathrm{l}(95.51 \%)$ in Sadamota in the dark condition (Table 2).

Table-2. Effect of 2,4-D and different culture medium composition on frequencies of callus formation among the Local rice cultivars.

\begin{tabular}{|c|c|c|c|}
\hline Cultivars & Treatments & $\begin{array}{c}\text { Callus } \\
\text { induction } \\
\text { (dark) }\end{array}$ & $\begin{array}{c}\text { Callus } \\
\text { induction } \\
\text { (light) }\end{array}$ \\
\hline \multirow{6}{*}{ Moulata } & $\mathrm{T}_{1}$ & $67.59 \mathrm{~lm}$ & $66.10 \mathrm{kl}$ \\
\hline & $\mathrm{T}_{2}$ & $71.80 \mathrm{j}-1$ & $67.37 \mathrm{kl}$ \\
\hline & $\mathrm{T}_{3}$ & $76.57 \mathrm{~h}-\mathrm{j}$ & $70.92 \mathrm{jk}$ \\
\hline & $\mathrm{T}_{4}$ & $81.28 \mathrm{e}-\mathrm{h}$ & $78.92 \mathrm{e}-\mathrm{h}$ \\
\hline & $\mathrm{T}_{5}$ & $85.50 \mathrm{~d}-\mathrm{f}$ & $82.70 \mathrm{~d}-\mathrm{f}$ \\
\hline & $\mathrm{T}_{6}$ & $90.52 \mathrm{~b}-\mathrm{d}$ & $88.05 \mathrm{~b}-\mathrm{d}$ \\
\hline \multirow{6}{*}{ Sadamota } & $\mathrm{T}_{1}$ & $78.48 \mathrm{~g}-\mathrm{i}$ & $75.16 \mathrm{~h}-\mathrm{j}$ \\
\hline & $\mathrm{T}_{2}$ & $79.79 \mathrm{f}-\mathrm{i}$ & $76.07 \mathrm{~g}-\mathrm{j}$ \\
\hline & $\mathrm{T}_{3}$ & $100.00 \mathrm{a}$ & $92.93 \mathrm{ab}$ \\
\hline & $\mathrm{T}_{4}$ & $89.15 \mathrm{~cd}$ & $87.01 \mathrm{~cd}$ \\
\hline & $\mathrm{T}_{5}$ & $84.40 \mathrm{~d}-\mathrm{g}$ & $80.16 \mathrm{e}-\mathrm{h}$ \\
\hline & $\mathrm{T}_{6}$ & $95.51 \mathrm{ab}$ & $93.90 \mathrm{a}$ \\
\hline \multirow{6}{*}{ Dudhkalam } & $\mathrm{T}_{1}$ & $63.44 \mathrm{~m}$ & $63.13 \mathrm{~lm}$ \\
\hline & $\mathrm{T}_{2}$ & $87.09 \mathrm{de}$ & $81.15 \mathrm{e}-\mathrm{g}$ \\
\hline & $\mathrm{T}_{3}$ & $69.35 \mathrm{kl}$ & $59.28 \mathrm{~m}$ \\
\hline & $\mathrm{T}_{4}$ & $74.24 \mathrm{i}-\mathrm{k}$ & $66.28 \mathrm{kl}$ \\
\hline & $\mathrm{T}_{5}$ & $76.93 \mathrm{~h}-\mathrm{j}$ & $75.42 \mathrm{~g}-\mathrm{j}$ \\
\hline & $\mathrm{T}_{6}$ & $79.78 \mathrm{f}-\mathrm{i}$ & $78.03 \mathrm{f}-\mathrm{i}$ \\
\hline \multirow{6}{*}{ Kachamota } & $\mathrm{T}_{1}$ & $76.74 \mathrm{~h}-\mathrm{j}$ & $73.10 \mathrm{ij}$ \\
\hline & $\mathrm{T}_{2}$ & $77.02 \mathrm{~h}-\mathrm{j}$ & $75.41 \mathrm{~g}-\mathrm{j}$ \\
\hline & $\mathrm{T}_{3}$ & $94.60 \mathrm{a}-\mathrm{c}$ & $90.80 \mathrm{a}-\mathrm{c}$ \\
\hline & $\mathrm{T}_{4}$ & $86.29 \mathrm{de}$ & $84.26 \mathrm{de}$ \\
\hline & $\mathrm{T}_{5}$ & 82.68 e-h & $76.65 \mathrm{~g}-\mathrm{j}$ \\
\hline & $\mathrm{T}_{6}$ & 89.87 b-d & $86.95 \mathrm{~cd}$ \\
\hline $\mathrm{LSD}_{0.05}$ & & 5.39 & 5.02 \\
\hline Level of sig. & & $* *$ & $* *$ \\
\hline $\mathrm{CV}(\%)$ & & 4.02 & 3.93 \\
\hline
\end{tabular}

Here ** represents the level of significant at $1 \%$ level of probability.

$\mathrm{T}_{1}=\mathrm{MS}+2,4-\mathrm{D}(2 \mathrm{mg} / \mathrm{l})+$ sucrose $(30 \mathrm{~g} / \mathrm{l})+$ gelrite $(6.4 \mathrm{~g} / \mathrm{l}) ; \mathrm{T}_{2}=\mathrm{MS}+2,4-\mathrm{D}(2 \mathrm{mg} / \mathrm{l})+$ maltose $(30 \mathrm{~g} / \mathrm{l})$ + gelrite $(6.4 \mathrm{~g} / \mathrm{l}) ; \mathrm{T}_{3}=\mathrm{MS}+2,4-\mathrm{D}(2 \mathrm{mg} / \mathrm{l})+\mathrm{L}-$ proline $(0.5 \mathrm{~g} / \mathrm{l})+\mathrm{L}$-glutamine $(0.5 \mathrm{~g} / \mathrm{l})+$ sucrose $(30$ $\mathrm{g} / \mathrm{l})+$ gelrite $(6.4 \mathrm{~g} / \mathrm{l}) ; \mathrm{T}_{4}=\mathrm{MS}+2,4-\mathrm{D}(2 \mathrm{mg} / \mathrm{l})+\mathrm{L}-$ proline $(0.5 \mathrm{~g} / \mathrm{l})+\mathrm{L}$-glutamine $(0.5 \mathrm{~g} / \mathrm{l})+$ maltose $(30$ $\mathrm{g} / \mathrm{l})+$ gelrite $(6.4 \mathrm{~g} / \mathrm{l}) ; \mathrm{T}_{5}=\mathrm{MS}+2,4-\mathrm{D}(3 \mathrm{mg} / \mathrm{l})+$ kinetin $(10 \mathrm{mg} / \mathrm{l})+$ maltose $(30 \mathrm{~g} / \mathrm{l})+$ gelrite $(4 \mathrm{~g} / \mathrm{l})+$ $\operatorname{agar}(2 \mathrm{~g} / \mathrm{l}) ; \mathrm{T}_{6}=\mathrm{MS}+2,4-\mathrm{D}(3 \mathrm{mg} / \mathrm{l})+$ kinetin $(10$ $\mathrm{mg} / \mathrm{l})+$ sucrose $(30 \mathrm{~g} / \mathrm{l})+\mathrm{gelrite}(4 \mathrm{~g} / \mathrm{l})+\operatorname{agar}(2 \mathrm{~g} / \mathrm{l})$.

Moreover, MS media containing 2,4-D (2 mg/l) exhibited the lowest $(63.44 \%)$ callus rate in Dudhkalam in the dark condition (Table 2). However, in light condition, 2, 4-D (3 mg/l) + kinetin $(10 \mathrm{mg} / \mathrm{l})$ showed the maximum $(93.90 \%)$ callus frequency followed 2,4-D (2 mg/l) (92.93\%) in Sadamota at dark condition (Table 2). MS media containing 2,4-D $(2 \mathrm{mg} / \mathrm{l})$ exhibited the minimum $(59.28 \%)$ callus frequency in Dudhkalam at dark conditions (Table 2).

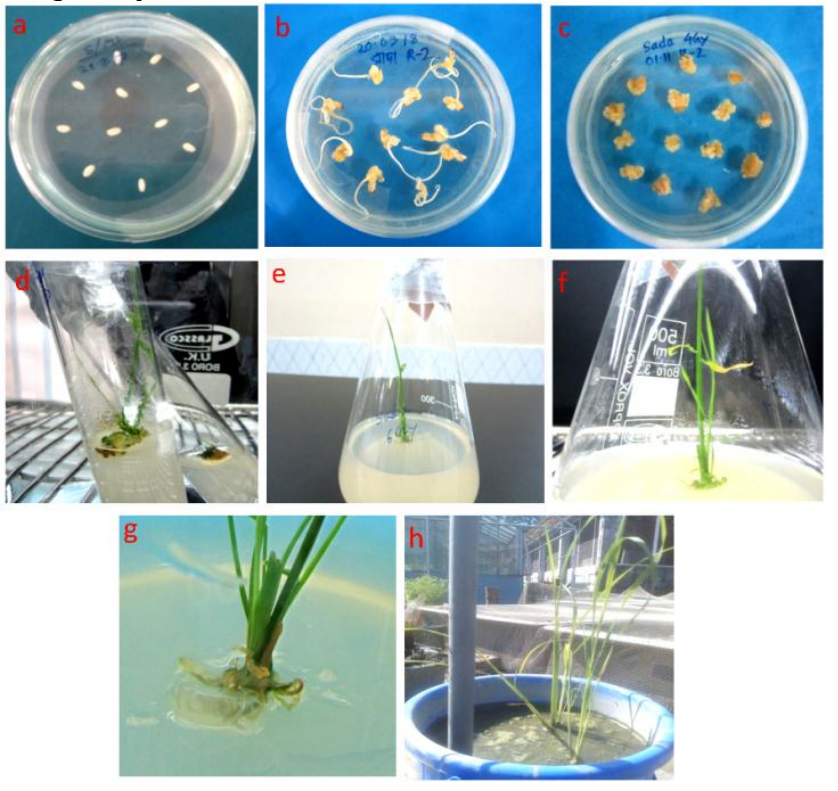

Figure-1. Photographic representation of a complete regeneration in the cultivar, Sadamota

\section{Effect of medium composition on callus formation at dark condition}

Carbon sources significantly affected the callus induction of rice. With 2,4-D (2mg/l), sucrose $\left(\mathrm{T}_{1}\right.$ and $T_{3}$ ) and maltose $\left(T_{2}\right.$ and $\left.T_{4}\right)$ were used with culture medium in the dark condition. Medium with sucrose as carbon source showed the highest $(100 \%)$ callus induction in Sadamota followed by Kachamota (94.60\%) (Table 2). Moreover, the lowest callogenesis rate was found in medium with maltose as the carbon source in Dudhkalam (63.44\%). However, with 2, 4-D $(3 \mathrm{mg} / \mathrm{l})+10 \mathrm{mg} / \mathrm{L}$ kinetin, sucrose $\left(\mathrm{T}_{6}\right)$ and maltose (T5) were used with MS medium in the dark condition L-proline. Medium with sucrose as carbon source showed the highest $(95.51 \%)$ callus induction in Sadamota followed by Moulota (90.52\%) (Table 2). Moreover, the lowest callogenesis rate was observed 


\section{Md Taufiqur Rahman et al}

in medium with maltose as the carbon source in Dudhkalam (76.93\%). The effect of solidifying agents was tested $\left(\mathrm{T}_{1}, \mathrm{~T}_{2}, \mathrm{~T}_{5}\right.$ and $\left.\mathrm{T}_{6}\right)$ at 2,4-D $(2 \mathrm{mg} / \mathrm{l})$ and 2,4-D (3 mg/l ) + 10 kinetin (mg/l ) under dark condition. The combined treatment of gelrite and agar exhibited the highest callus induction rate in Sadamota followed by Moulota at 2,4-D (2 mg/l) whereas the lowest was found in Dudhkalam. A combination of Lglutamine was applied with either sucrose $\left(\mathrm{T}_{3}\right)$ or maltose $\left(T_{4}\right)$ in a culture medium in the dark condition. In this condition, the genotypes Sadamota showed the maximum callus induction frequency which was followed by Kachamota whereas the lowest was found in Dudhkalam.

\section{Effects of NAA on shoot regeneration}

For optimizing regeneration potential, the calli were carefully cultured on the regeneration medium supplemented with two different concentrations of NAA $(0.5$ and $1 \mathrm{mg} / \mathrm{l})$ along with kinetin $(10 \mathrm{mg} / \mathrm{l})$. The NAA treatments significantly affected the regeneration potential (Fig. 3). After 2 weeks, green like spots were initiated into the transferred embryogenic calli. Shoot regeneration in various cultivars ranged from $27.1 \%$ to $58.22 \%$. Between the two different concentrations of NAA along with 10 $\mathrm{mg} / \mathrm{l}$ kinetin tested, MS media containing NAA $(0.50$ $\mathrm{mg} / \mathrm{l})$ exhibited the highest (66.44\%) shoot regeneration followed by Kachamota (50.61\%) whereas the lowest was observed in Dudhkalm at NAA $(0.25 \mathrm{mg} / \mathrm{l})(18.33 \%)$ (Fig. 3a). Moreover, between the two different concentrations of NAA along with $10 \mathrm{mg} / \mathrm{l}$ kinetin tested, MS media containing NAA $(0.50 \mathrm{mg} / \mathrm{l})$ exhibited the maximum (4.48) number of shoot callus followed by Kachamota (3.11) whereas the lowest was observed in Dudhkalm (1.7) at NAA $(0.25 \mathrm{mg} / \mathrm{l})$ (Fig. 3b).

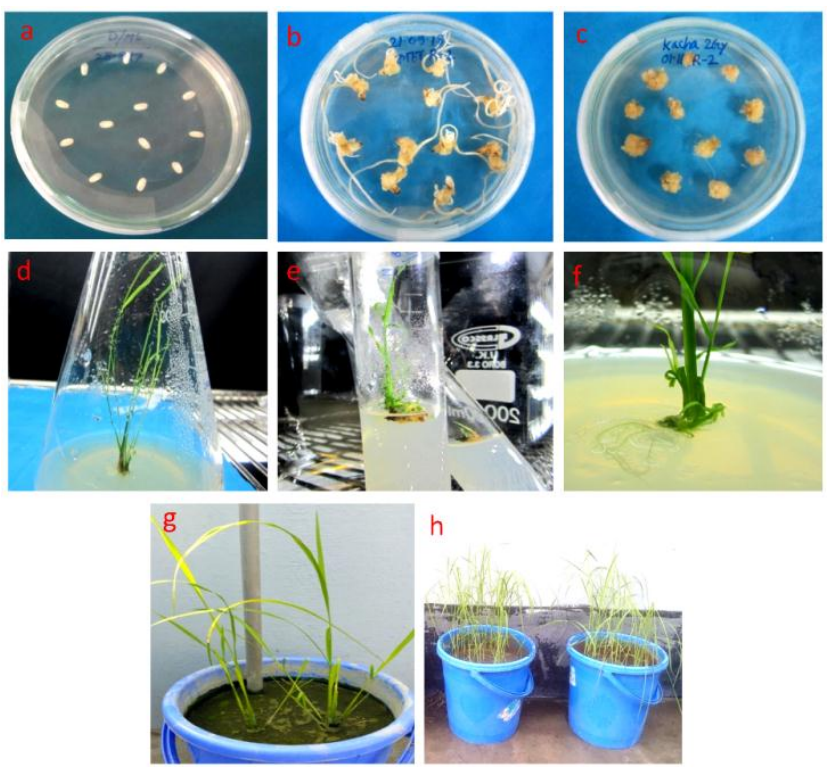

Figure-2. Photographic representation of a complete regeneration in the cultivar, Kachamota

\section{Effects of IBA on root induction}

Root induction in various cultivars significantly ranging from 38.58 to $63.93 \%$.Between the two different concentrations of IBA tested, MS media containing $0.50 \mathrm{mg} / \mathrm{l}$ exhibited the highest $(71.33 \%)$ root induction followed by Kachamota $(66 \%)$ whereas the lowest was observed in Dudhkalm at $0.25 \mathrm{mg} / \mathrm{l}$ IBA (33.44\%) (Fig. 4a). Moreover, between the two different concentrations of NAA along with $10 \mathrm{mg} / \mathrm{l}$ kinetin tested, MS media containing $0.25 \mathrm{mg} / \mathrm{l}$ exhibited the highest (9.33) number of root callus followed by Kachamota (8.39) whereas the lowest was observed in Dudhkalm at $0.25 \mathrm{mg} / \mathrm{l}$ NAA (3.72) (Fig. 4b). The rooted plantlets were successfully transferred in soil.

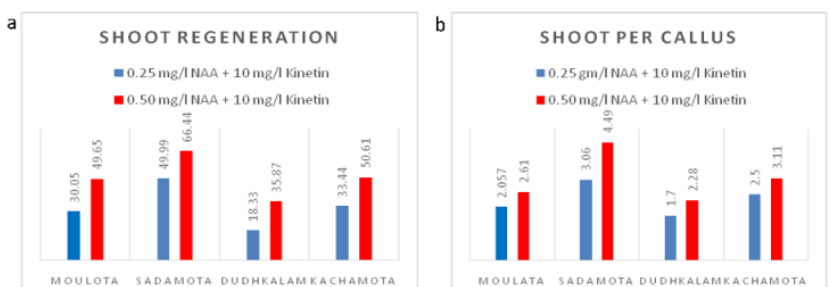

Figure-3. Graphic representation of the effect of NAA and kinetin on the percentage (a) shoot induction and (b) shoot number per callus in localindica rice 


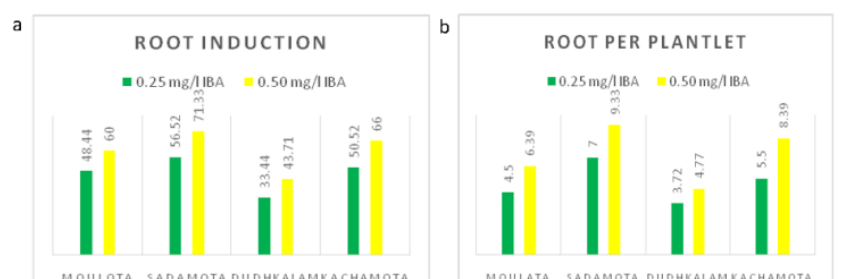

Figure-4. Graphic representation of the effect of IBA on the percentage (a)root induction and (b)root number per regenerated plant in local indica rice.

\section{Discussion}

It was revealed by many experiments that an organic compound, Auxin, 2,4-D was an essential factor for effectual callogenosis in rice ( Joyia and Khan, 2013; Islam et al., 2020) but many scientists used 2,4-D in combination with cytokinin or kinetin (Sahoo et al., 2011). Moreover, 2,4-D was determined as indispensable plant hormones for callus based in vitro micro-propagation. Many studies evidenced that the callus formation rate in indica rice was significantly affected in both dark and light conditions (CMZ et al., 2017; Trunjaruen et al., 2020). Our result revealed that a single treatment of 2,4-D (2 mg/l) exhibited the greater frequencies $(100 \%)$ of callus induction among the four cultivars. We also found that 2, 4-D (3 mg/l) along with kinetin $(10 \mathrm{mg} / \mathrm{l})$ showed significant callus frequency $(88.92 \%)$. However, our test demonstrated that in dark conditions, the maximum callus induction was displayed in only 2,4-D treatment $(2 \mathrm{mg} / \mathrm{l})$ (Table 2).

The cultivars Sadamota showed the best performance for callus formation which was followed by Kachamota. our present results were also in agreement with many previously described reports on indica rice (Ali et al., 2004; Shahsavari, 2010; Rattana et al., 2012; Azizi et al., 2015; Ahmad et al., 2016; Artadana et al., 2017; Ho et al., 2018; Trunjatuen et al., 2020) and bread wheat (Hasanuzzaman et al. 2021). However, callus induction in indica rice is significantly influenced by the medium components such as carbon source, amino acids and solidifying agents described in several past experiments (Binte Mostafiz and Wagiran, 2018; Repalli et al., 2019). Our present studies further revealed that sucrose produced the highest callus in all cultivars than maltose when it is as carbon source (table 2). Moreover, the L-proline and L-glutamine improved the callus induction rate as compared to the nontreated medium. Moreover, gel rite and agar combined treatment as a solidifying agent showed better callus proliferation than when they treated alone in callus induction medium. In this condition, the cultivar Sadamota showed the best performance for callus induction followed by Kachamota. Our current experiments were in concord with findings of (Bala et al., 2015), (Binte Mostafiz and Wagiran, 2018), and (Repalli et al., 2019).

The plant growth regulators e.g auxins and cytokinins are responsible for promoting the frequency of regeneration in some recalcitrant grain crops including rice (Rueb et al., 1994; Lee et al., 2002). In the current research, the cultivar Sadamota displayed the highest $(66.44 \%)$ regeneration frequency followed by Kachamota at $0.50 \mathrm{mg} / \mathrm{l} \mathrm{NAA}+10 \mathrm{mg} / \mathrm{l} \mathrm{kinetin}$ (Fig $3 a)$. With the increasing concentrations of NAA were increased from $0.25 \mathrm{mg} / \mathrm{l}$ to $0.50 \mathrm{mg} / \mathrm{l}$, the shoot regeneration rates were increased. The increased amount of NAA may help the callus growth, morphology, cell differentiation and green spot formation thereby increased plant regeneration. Moreover, the shoot number per callus was also increased with the increase of NAA concentration 0.25 to $0.50 \mathrm{mg} / \mathrm{l}$. Increased NAA also improves the total callus morphology and regeneration there produce increased shoot in callus. The cultivar Sadamota showed the highest (4.49) number of shoot per callus followed by Kachamota at $0.50 \mathrm{mg} / \mathrm{l} \mathrm{NAA}$ with the combination of $\mathrm{K} 10 \mathrm{mg} / \mathrm{l}$ kinetin (Fig. 3b). (Ahmad et al., 2016) observed a regeneration with the treatment of NAA, Kinetin and other cytokinins in Malaysian upland rice. It is found some similar results in various studies using rice seed (Libin et al., 2012; Saha et al., 2017; Ho et al., 2018; Binte Mostafiz and Wagiran, 2018; Islam et al., 2020).

IBA, an important plant growth regulator, promotes in vitro rooting in rice and several crop plants (Elaleem et al., 2009; Yusnita et al., 2017). In our experiments, the cultivar Sadamota showed the highest (71.33\%) root induction followed by Kachamota at $0.50 \mathrm{mg} / \mathrm{l} \mathrm{IBA}$ (4a). When the IBA concentration was raised from $0.25-0.50 \mathrm{mg} / \mathrm{l}$, the rooting rate was increased. The increased amount of IBA may help the root growth, development, cell differentiation thereby increased rice root induction. Moreover, the roots number per regenerated plantlet was also increased with the increase of IBA concentration 0.25 to $0.50 \mathrm{mg} / \mathrm{l}$ (Fig. $4 b$ ). The cultivar Sadamota showed the highest (9.33) number of root per plant followed by Kachamota at $0.50 \mathrm{mg} / \mathrm{l}$ of IBA. Similar results were also observed in various studies suing rice and other plants (Elaleem et 
al., 2009; Alam et al., 2012; Mukherjee et al., 2015; Abiri et al., 2017; Kumar et al., 2017; Yusnita et al., 2017; Wang et al., 2020).

\section{Conclusion}

The current investigation describes an efficient and complete regeneration protocol that was generated from mature seeds of indica rice. The optimum callus frequencies concentration were exhibited by culture medium added with $2,4-\mathrm{D}(2 \mathrm{mg} / \mathrm{l})$, L-glutamine, $\mathrm{L}$ proline, sucrose $(30 \mathrm{mg} / \mathrm{l})$ and gel rite alone (as solidifying agent). Moreover, highly efficient regeneration was optimized using a regeneration medium supplemented with NAA $(0.5 \mathrm{mg} / \mathrm{l})+$ Kinetin $(10 \mathrm{mg} / \mathrm{l})$. Besides, the addition of IBA $(0.50 \mathrm{mg} / \mathrm{l})$ in the rooting medium exhibited the most effective response for root induction and root number. This regenerated protocol could further be used in successful genetic transformation by incorporating improved agronomic traits.

\section{Acknowledgement}

The authors are grateful to the Ministry of Agriculture of the People's Republic of Bangladesh, for financial help and also acknowledge Biotechnology Division of Bangladesh Institute of Nuclear Agriculture (BINA) for technical support.

Disclaimer: None.

Conflict of Interest: None.

Source of Funding: Ministry of Agriculture, the People's Republic of Bangladesh

\section{References}

Abiri R, Maziah M, Shaharuddin N, Yusof Z, Atabaki N, Hanafi M, Sahebi M, Azizi P, Kalhori N and Valdiani A, 2017. Enhancing somatic embryogenesis of Malaysian rice cultivar MR219 using adjuvant materials in a high-efficiency protocol. Int. J. Environ. Sci. Technol. 14: 1091-1108.

Ahmad FI, Wagiran A, Abd Samad A, Rahmat Z and Sarmidi MR, 2016. Improvement of efficient in vitro regeneration potential of mature callus induced from Malaysian upland rice seed (Oryza sativa cv. Panderas). Saudi J.
Biol. Sci. 23:69-77.

Alam M, Imran M, Hassan L, Rubel $M$ and Shamsuddoha M, 2012. In vitro regeneration of high yielding indica rice (Oryza sativa L.) varieties. J. Environ. Sci. Natur. Res. 5: 173177.

Ali S, Qing-Zhong X and Xinan-Yin Z, 2004. Assessment of various factors involved in the tissue culture system of rice. Rice Sci. 11: 345349.

Artadana IBM, Suhono GBF, Hardjo PH, Purwanto MGM and Supaibulwatana K, 2017. Plant regeneration induced from mature Embryoderived callus of Balinese red rice (Oryza sativa Cv. Barak Cenana). Bali Med. J. 6: 12-17.

Azizi P, Rafii MY, Mahmood M, Hanafi MM, Abdullah SNA, Abiri R and Sahebi M, 2015. Highly efficient protocol for callogenesis, somagenesis and regeneration of Indica rice plants. Com. Ren. Boil. 338: 463-470.

Bala R, Beniwal VS and Laura JS, 2015. An efficient and reproducible indirect shoot regeneration from female leaf explants of Simmondsia chinensis, a liquid-wax producing shrub. Physiol. Mol. Biol. Plants 21: 293-299. doi: 10.1007/s12298-015-0279-1

BBS (Bangladesh Bureau of Statistics), 2016. Yearbook of Agricultural Statistics, 28th Series, Statistics and Informatics Division (SID) Ministry of Planning. 2016: 33-36.

Binte Mostafiz S and Wagiran A, 2018. Efficient callus induction and regeneration in selected indica rice. Agron. 8: 77.

Cai X, Wang G and Cao W, 2013. In vitro induction and proliferation of callus from immature cotyledons and embryos of Juglans regia cv.'Xiangling'. Notulae Botanicae, Horti Agrobotanici, Cluj-Napoca 41: 378-384.

CMZ CR, Alhasnawi AN, Kadhimi AA, Isahak A, Mohamad A, Ashraf MF, Doni F and Yusoff WMF, 2017. Development of a Technique for Callus Induction and Plant Regeneration in Oryza sativa L. var. MRQ74 and MR269. Adv. J. Food Sci. Technol. 13: 128-137.

Elaleem K, Modawi RS and Khalafalla MM, 2009. Effect of plant growth regulators on callus induction and plant regeneration in tuber segment culture of potato (Solanum tuberosum 
L.) cultivar Diamant. Afr. J. Biotechnol. 8. 2529-2534

Feng X, Zhao P, Hao J, Hu J, Kang D and Wang H, 2011. Effects of sorbitol on expression of genes involved in regeneration of upland rice (Oryza sativa L.). Plant Cell, Tissue Org. Cult. 106: 455-463.

Ge X, Chu Z, Lin Y and Wang S, 2006. A tissue culture system for different germplasms of indica rice. Plant Cell Reports. 25: 392-402.

Gosal SS and Kang MS, 2012. Plant tissue culture and genetic transformation for crop improvement. In Imp. Crop Res. Abio. Stress.

Hasanuzzaman M, Islam MM, Saha NR, Farabi S and

Haque MS, 2021. In-vitro callogenesis and regeneration from mature embryos of Bangladeshi wheat (Triticum aestivum L.) cultivars. Plant cell Biotechnol. and Mol. Biol. 22(33 \& 34): 381-390.

Ho TL, Sompong TC and Yenchon S, 2018. Callus Induction and Plantlet Regeneration Systems in Indica Rice (Oryza sativa L.) Cultivar Sangyod. Walailak J. Sci. Technol. 15: 753-763.

Islam MM, Rahman MT, Hasanuzzaman M, Islam MS, Uddin, MI and Saha NR, 2020. In vitro response and effect of gamma irradiation on four local indica rice varieties. J. Sci. Agric. 4: 90-92.

Joyia FA and Khan MS, 2013. Scutellum-derived callus-based efficient and reproducible regeneration system for elite varieties of indica rice in Pakistan. Int. J. Agric. Biol. 15: 15608530.

Kavas M, Öktem H and Yücel M, 2008. Factors affecting plant regeneration from immature inflorescence of two winter wheat cultivars. Biol. Planta. 52: 621-626.

Kumar R, Mamrutha HM, Kaur A, Venkatesh K, Grewal A, Kumar Raj and Tiwari V, 2017. Development of an efficient and reproducible regeneration system in wheat (Triticum aestivum L.). Physiol. Mol. Biol. Plants. 23: 945-954.

Lee K, Jeon H and Kim M, 2002. Optimization of a mature embryo-based in vitro culture system for high-frequency somatic embryogenic callus induction and plant regeneration from japonica rice cultivars. Plant Cell Tissue Organ Cult. 71: 237244.
Libin A, King P, Ong K, Chubo J and Sipen P, 2012. Callus induction and plant regeneration of Sarawak rice (Oryza sativa L.) variety Biris. African J. Agric. Res. 7: 4260-4265.

Maharani A, Fanata WID, Laeli FN, Kim KM and Handoyo T, 2020. Callus Induction and Regeneration from Anther Cultures of Indonesian Indica Black Rice Cultivar. J. Crop Sci. Biotechnol. 23: 21-28.

Ming N, Binte Mostafiz S, Johon NS, Abdullah Zulkifli NS and Wagiran A, 2019. Combination of plant growth regulators, maltose, and partial desiccation treatment enhance somatic embryogenesis in selected Malaysian rice cultivar. Plants. 8: 144.

Mukherjee A, Islam M, Nasiruddin K and Banerjee $\mathrm{P}, 2015$. Study on callus initiation and plantlet regeneration ability of some rice genotypes. Int. J. Sci. Tech. Res. 4: 354-361.

Parmar SS, Sainger M, Chaudhary D and Jaiwal $\mathrm{PK}$, 2012. Plant regeneration from mature embryo of commercial Indian bread wheat (Triticum aestivum L.) cultivars. Physiol. Mol. Biol. Plants. 18: 177-183.

Ramesh M, Murugiah V and Gupta AK, 2009. Efficient in vitro plant regeneration via leaf base segments of indica rice (Oryza sativa L.). Indian J. Exp. Bot. 2009 47: 68-74.

Rattana K, Theerakulpisut P and Bunnag S, 2012. The effect of plant growth regulators and organic supplements on callus induction and plant regeneration in rice (Oryza sativa L.). Asian J. Plant Sci. 11: 182-189.

Repalli S, Geda C, NSN P and G R, 2019. Influence of Media Type and Carbon Source on Callus Induction and Regeneration Response of Different Indica Rice Genotypes. Adv. Crop Sci. Tech 7: 2. DOI: 10.4172/23298863.1000425

Rueb, S, Leneman, M, Schilperoort, RA and Hensgens, L, 1994. Efficient plant regeneration through somatic embryogenesis from callus induced on mature rice embryos (Oryza sativa L.). Plant Cell Tissue Organ Cult. 36: 259-264.

Saha D, Bhavya C and Ashok T, 2017. Effect of genotypes and different concentration of growth regulator on callus induction and plant regeneration through anther culture of rice. J. 
Pharmacog. Phytochemis. 6: 1354-1358.

Sahoo KK, Tripathi AK, Pareek A, Sopory SK and Singla-Pareek SL, 2011. An improved protocol for efficient transformation and regeneration of diverse indica rice cultivars. Plant methods. 7: $1-11$.

Sandhu N and Kumar A, 2017. Bridging the rice yield gaps under drought: QTLs, genes, and their use in breeding programs. Agron. 7: 27.

Shahsavari E, 2010. Evaluation and optimizations of media on the tissue culture system of upland rice. Int. J. Agric. Biol. 12: 537-540.

Shamsuzzaman K and Haque M, 2010. Performance of modern varieties of transplanted aman rice and mungbean in selected locations in tidal floodplain. Crop Production in the Coastal Ecosystem-Challenges and Opportunities, Agrarian Research Foundation, Dhaka 26-30.

Shariatpanahi ME, Belogradova K, Hessamvaziri L, Heberle-Bors E and Touraev A, 2006. Efficient embryogenesis and regeneration in freshly isolated and cultured wheat (Triticum aestivum L.) microspores without stress pretreatment. Plant Cell Reports. 25: 1294-1299.

Trunjatuen A, Sayam R, Maneerattanarungroj P and Taratima W, 2020. Effects of Cultivation Media on In vitro Callus Induction and Regeneration Capabilities of Pakaumpuel Rice (Oryza sativa L.), Thai Rice Landrace. Walailak J. Sci. Technol. 17: 37-46.

Ullah MJ, Islam MA, Harun-or-Rashid M, Rahman MM, Siddique M, Akbar MA, Razzaque MA, Mollah MFH and Hamid A, 2016. Evaluation of Indigenous and High Yielding Rice Varieties for Growing in Tidal Floodplain Ecosystem of Southern Bangladesh. Agric. Forest. Fisher. 5:
237.

Vaughan DA, Morishima H and Kadowaki K, 2003. Diversity in the Oryza genus. Curr. Opin. Plant Boil. 6: 139-146.

Wang F, Xin X, Wei H, Qiu X and Liu B, 2020. In Vitro Regeneration, Ex Vitro Rooting and Foliar Stoma Studies of Pseudostellaria heterophylla (Miq.) Pax. Agron. 10: 949.

Yu Y, Wang J, Zhu $\mathrm{M}$ and Wei Z, 2008. Optimization of mature embryo- based high frequency callus induction and plant regeneration from elite wheat cultivars grown in China. Plant Breed. 127: 249-255.

Yusnita Y, Jamaludin J, Agustiansyah A and Hapsoro D, 2017. A combination of IBA and NAA resulted in better rooting and shoot sprouting than single auxin on Malay apple [Syzygium malaccense (L.) Merr. \& Perry] stem cuttings. AGRIVITA J. Agric. Sci. 40: 8090 .

\section{Contribution of Authors}

Rahman MT, Hasanuzzaman M: Conceived idea, research methodology, wrote original draft of manuscript, validated and visualized the research, read and approved the final manuscript.

Islam MM: Research methodology, performed software analysis, reviewed and edited manuscript, supervised the study, read and approved the final manuscript.

Mondal MTR \& Saha NR: Research methodology, performed formal analysis, reviewed and edited manuscript, read and approved the final manuscript. Islam MS: Reviewed and edited manuscript, supervised the study, read and approved the final draft. 